\section{BOOKS FOR COLLEGE LIBRARIES}

Books for College Libraries, a 1,072-page work listing more than fifty-three thousand books considered important for college libraries, has been scheduled for publication in March by the American Library Association.

The list of books, designed to support a college teaching program which depends heavily on the library, is expected to replace the obsolete List of Books for College Libraries prepared by the late Charles B. Shaw, which ALA published in 1931 .

Books for College Libraries has been developed by the ALA Editorial Committee in close cooperation with librarians at the University of California, who developed a basic list of basic books for three new undergraduate libraries in a New Campuses Program there. The ALA project was supported by a grant from the Council on Library Resources.

The new ALA list includes only titles published prior to 1964. Books issued since then are covered in Choice, a book review periodical published eleven times a year by ALA since March 1964-a project which has also been assisted by grants from the Council on Library Resources.

Books for College Libraries lists classics, important scholarly titles, and definitive works on all subjects of interest to the undergraduate student body, including out-of-print titles and original paperbacks. Of the total list, 32.2 per cent of the titles are in literature and language; 18.7 per cent in history; 20.8 per cent in social science; 8.9 per cent in religion, philosophy and psychology; 7.5 per cent in fine arts; 9.5 per cent in science; and 2.4 per cent in general and reference.

Titles are arranged by Library of Congress classification and are entered only once. Each entry includes full author, title, edition, imprint, main pagination, and LC card number. The list is indexed by author and subject.

The California list was prepared under the direction of Melvin J. Voigt, university librarian, University of California, San Diego.

\section{Subscription Price Change-}

Subscription to CRL will, after July 1, include 11 News issues as well as six bimonthly journal issues. Subscription orders postmarked after June I will be accepted only at the new rate- $\$ 10.00$ per year.
Joseph H. Treyz, formerly head of the California New Campuses Program and now assistant librarian, University of Michigan, directed the development and preparation of the book selection list by ALA. Subject specialists recognized for their expertise in evaluating undergraduate college library materials reviewed all selections.

\section{INVITATION TO JMRT MEMBERS}

ACRL has established an experimental program of Intern Committee Memberships for the year $1967 / 68$. Under this program, one extra, junior member of ACRL will be appointed to standing committees for a one-year term.

JMRT has an opportunity to recommend from among its membership the names of ACRL members for possible appointment to the committees listed below.

If there are any junior members who are also ACRL members and who are interested in working on any of these committees, will they please write to: Maurice S. Goldman, Chairman, JMRT, Willingboro Public Library, Willingboro Plaza, Willingboro, New Jersey 08046, giving the following information:
Name
Position
Professional Address
Mailing Address (If Different From Pro- fessional)
Name of Committee
Experience or Background That Qualifies You for Work on Named Committee.

Any persons submitting their names for consideration under this program should bear in mind that they will be expected to attend meetings whenever and wherever they may be called. Please submit your name only if you are willing to undertake the responsibility and expense of attending meetings and otherwise being active workers. Also, please keep in mind that final appointments will be made by ACRL only.

JMRT has an opportunity and a challenge in this program. I am looking forward to hearing from junior members of ACRL.

\section{ACRL Committees:}

Audio-Visual Committee

Advisory Committee on Cooperation with Educational \& Professional Organizations

Committee on Liaison with Accrediting Agencies

Committee on Library Services

Committee on Library Surveys

National Library Week Committee

Planning and Action Committee

Publications Committee

Committee on Standards 